\title{
Denis Boak, Malraux: «L’Espoir»
}

\section{Emanuele Kanceff}

\section{(2) OpenEdition}

\section{Journals}

\section{Edizione digitale}

URL: https://journals.openedition.org/studifrancesi/41162

DOI: 10.4000/studifrancesi.41162

ISSN: 2421-5856

\section{Editore}

Rosenberg \& Sellier

\section{Edizione cartacea}

Data di pubblicazione: 1 juillet 2004

Paginazione: 220

ISSN: 0039-2944

\section{Notizia bibliografica digitale}

Emanuele Kanceff, «Denis Boak, Malraux: «L'Espoir»», Studi Francesi [Online], 142 (XLVIII | I) | 2004,

online dal 30 novembre 2015, consultato il 09 septembre 2021. URL: http://journals.openedition.org/ studifrancesi/41162 ; DOI: https://doi.org/10.4000/studifrancesi.41162

\section{Questo documento è stato generato automaticamente il 9 septembre 2021.}

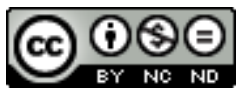

Studi Francesi è distribuita con Licenza Creative Commons Attribuzione - Non commerciale - Non opere derivate 4.0 Internazionale. 


\title{
Denis Boak, Malraux: «L'Espoir»
}

\author{
Emanuele Kanceff
}

\section{NOTIZIA}

DENIS BOAK, Malraux: «L'Espoir», London, Grant \& Cutler Ltd, 2003, pp. 88 («Critical Guides to French Texts», 131).

1 L'autore di questa sintetica lettura de L'Espoir considera questo «ambizioso» romanzo come un evento nel contesto letterario che lo ha visto nascere, in quanto, come Per chi suona la campana di Hemingway, appare come uno dei primi esempi di romanzo d'attualità. Professore emerito dell'University of Western Australia, autore già di un articolo su «L'Espoir from the Transient to the Timeless'» pubblicato nella «Revue André Malraux» nel 1987, Denis Boak ritorna su questo romanzo che, a suo vedere, rappresenta un punto cruciale nell'evoluzione dello scrittore francese, per mostrarne l'importanza sia dal punto di vista del pensiero politico, sia come tappa essenziale dell'evoluzione letteraria di André Malraux. 